\title{
KOMUNIKASI INSTRUKSIONAL GURU DAN SISWA TUNAGRAHITA BERPRESTASI
}

\author{
Lina Angris Risopani ${ }^{1}$, Femi Oktaviani ${ }^{2}$ \\ Ilmu Komunikasi, ARS University, Bandung, Indonesia
}

\begin{abstract}
ABSTRAK
Anak tunagrahita mengalami kesulitan berkomunikasi dan berinteraksi dengan lingkungan. Cara mereka berkomunikasi pun masih sangat rendah, terutama ketika mereka berada di lingkungan yang luas seperti lingkungan masyarakat. Penelitian ini bertujuan untuk mengetahui proses komunikasi verbal dan nonverbal, proses instruksional, dan motivasi anak tunagrahita. Penelitian ini menggunakan pendekatan kualitatif dengan studi kasus. Teknik pengumpulan data dilakukan dengan cara observasi, wawancara, dan dokumentasi. Hasil penelitian ini adalah komunikasi verbal yang digunakan berupa membaca dan mendengarkan, sementara komunikasi nonverbal berupa bahasa tubuh, komunikasi nonverbal memiliki fungsi aksentuasi karena bahasa tubuh mempertegas komunikasi verbal yang dilakukan guru. Proses instruksional mengunakan strategi ekspositori dan metode pembelajaran pengantara, metode pembelajaran drill, metode tanya jawab. Jenis motivasi yaitu motivasi ekstrinsik karena siswa tunagrahita mendapatkan dorongan dari luar dirinya.
\end{abstract}

\section{Kata kunci: Komunikasi, Instruksional, Tunagrahita}

\begin{abstract}
Children with intellectual disabilities have difficulties in communicating and interacting with the environment. Their way communication is not good, especially when they are in a broad environment like in the community. This study aims to know about verbal and nonverbal communication process, instructional processes, and motivation of Tunagrahita children. This research uses a qualitative approach with a case study. The data collection technique is used by using observation, interview, and documentation. The results of the research are verbal communication used in the form of reading and listening, meanwhile the nonverbal communication in the form of body language, nonverbal communication has accentuation functions because body language reinforces verbal communication by the teacher. The instructional process uses expository strategies and interstitial learning methods, drill learning methods, question and answer methods. Type of motivation is extrinsic motivation because students with intellectual disabilities get encouragement from outside themselves.
\end{abstract}

Keywords: Communication, Instructional, Tunagrahita.

\section{PENDAHULUAN}

Anak tunagrahita mengalami kesulitan berkomunikasi dan berinteraksi dengan lingkungan. Cara mereka berkomunikasi pun masih sangat rendah, terutama ketika mereka berada di lingkungan yang luas seperti lingkungan masyarakat. Memiliki IQ dibawah ratarata sehingga tidak dipungkiri lagi jika mereka mengalami kesulitan belajar. Dalam perkembangan sosial dan segi pendidikannya anak tunagrahita selalu 
tertinggal dari teman-teman sebayanya yang normal. Hal tersebut dapat terjadi karena mereka mempunyai hambatanhambatan sehingga mengalami kesulitan dalam mengembangkan potensi dirinya.

Anak tunagrahita mengalami hambatan dan permasalahan sehingga dalam pendidikannya mengalami hambatan dan permasalahan, akhirnya mengalami kesulitan belajar dan prestasinya rendah. Prestasi belajar yang rendah pada anak tunagrahita dipengaruhi oleh banyak faktor antara lain : Kondisi jasmani yang tidak menguntungkan, pemusatan perhatian yang kurang, minat belajar yang rendah, dorongan ingin tahu rendah, disiplin yang kurang, intelegensi yang rendah, dan kemampuan daya ingat lemah. (Sudjana, 2003)

Selain itu, hambatan yang dimilki anak tunagrahita mempengaruhi tingkat pencapaian prestasi. Kenyataannya tidak sedikit dari mereka bisa menoreh prestasi. Baik di bidang akademik maupun non akademik. (Delphie, 2006).

Dari data harian berita Republika: Dua siswa menengah atas tunagrahita mampu mencetak prestasi. Pertama, Arman (20 tahun) menorehkan prestasi di kancah nasional dengan menyabet dua medali pada ajang kejuaraan renang di Paralymic Bandung. Dengan skor IQ 55. Kedua, Raka Nurmujahidin (18 tahun) menorehkan prestasi juara 1 dalam lomba karya tulis dari Kementerian Pendidikan dan Kebudayaan.

Dari uraian fenomena diatas, peneliti memutuskan untuk melakukan penelitian tentang siswa tunagrahita yang berprestasi. Bagaimana bisa mereka mampu mencetak prestasi seperti anak-anak normal lainnya. IQ mereka dibawah rata-rata dan untuk bisa berkomunikasi saja mereka kesulitan. Padahal komunikasi adalah dasar dari seseorang untuk bisa berinterkasi dengan orang lain.

Peneliti mengambil Sekolah Luar Biasa C (SLB C) Sukapura Bandung sebagai tempat penelitian karena di sekolah tersebut memang dikhususkan bagi anak-anak berkebutuhan khusus terutama yang mempunyai kemampuan intelektual di bawah rata-rata atau tunagrahita dengan karakteristik tunagrahita ringan dan tunagrahita sedang. Mulai dari SD, SMP, dan SMA. SLB C Sukapura banyak menyimpan siswa-siswa tunagrahita yang berhasil mencetak prestasi pada bidang literasy, olahraga, kesenian, dll. Kejuaraan yang 
didapat mulai dari tingkat Kotamadya, Provinsi, bahkan Nasional. Peneliti memilih siswa tunagrahita berprestasi dalam bidang kesenian menggambar dan mewarnai sebagai fokus penelitian.

Lewat peran guru, siswa tunagrahita dilatih untuk bisa berkomunikasi dengan baik. Komunikasi di dalam dunia pendidikan biasa disebut komunikasi instruksional. Komunikasi instruksional merupakan komunikasi yang dipola dan dirancang secara khusus untuk mengubah perilaku sasaran dalam komunitas tertentu ke arah yang lebih baik. Komunikasi instruksional sendiri dirancang untuk memberikan aspek kognisi, afeksi dan konasi atau psikomotorik (Yusuf, 2010)

Guru (komunikator) dan siswa (komunikan atau sasaran) sama-sama melakukan interaksi psikologis yang nantinya diharapkan bisa berdampak pada berubahnya pengetahuan, sikap, dan keterampilan di pihak komunikan. Proses interaksi psikologis ini berlangsung paling tidak antara dua orang dengan cara berkomunikasi. Dalam situasi formal, proses ini terjadi ketika sang komunikator berupaya membantu terjadinya perubahan tadi, atau proses belajar di pihak sasaran atau komunikan. Teknik atau alat untuk melakukan proses ini adalah komunikasi, yaitu komunikasi instruksional.

Anak tunagrahita masih dipandang sebelah mata oleh sebagian masyarakat karena kekurangan yang dimiliki, namun pada dasarnya mereka itu baik dan justru dapat mengembangkan potensi mereka dengan meraih berbagai prestasi. Pola pikir siswa tunagrahita dibentuk ketika mereka melakukan studi atau ketika mereka berada di sekolah lewat peran seorang guru. Pola pikir adalah gerbang awal menuju sebuah prestasi. Dengan menggunakan ide-ide baru guru dapat membangun prestasi siswa tunagrahita.

Berdasarkan fenomena bahwa siswa tunagrahita yang memiliki banyak kekurangan dan hambatan dalam berprestasi justru mampu mencetak prestasi seperti siswa normal lainnya melalui peran yang dilakukan seorang guru, maka peneliti memiliki ketertarikan untuk mengetahui Komunikasi Instruksional Guru kepada Siswa Tunagrahita dalam Membangun Prestasi dalam Bidang Kesenian Menggambar dan Mewarnai di SLB C Sukapura Bandung. 
Komunikasi

Instruksional

merupakan kegiatan komunikasi dengan sasaran kelompok yang berisi pengajaran tentang suatu pengetahuan atau keterampilan tertentu. Dalam komunikasi instruksional baik yang formal, tujuan utama yang harusdicapai didalamnya adalah terjadinya perilaku peserta didik (Syam dalam Khalilah,2008).

Komunikasi Instruksional berarti komunikasi dalam bidang instruksional. Dengan demikian, apabila ingin membicarakan komunikasi instruksional, maka dengan sendirinya kita tidak bisa lepas dari pembahasan mengenai kata atau instruksional itusendiri. Istilah instruksional berasal dari kata instruction. Ini bisa berarti pengajaran, pelajaran, atau bahkan perintah atau instruksi. Hal ini bisa dilihat pada kamus-kamus bahasa. Baik yang umum dalam satu bahasa maupun dalam dua bahasa.

Komunikasi instruksional dalam proses pelaksanaannya mengandung unsur-unsur kegiatan instruksional, mencakup peristiwa yang luas seperti dikatakan oleh Gagne dan Brigge (dalam Mudhofir dalam Muhammad Surip), yaitu "cara yang dipakai oleh guru, ahli kurikulum, perancang bahan dan alinlain yang bertujuan untuk mengembangkan recana yang terorganisasi guna keperluan belajar." Di dalam dunia pendidikan, kata instruksional tidak diartikan perintah tetapi lebih mendekati kedua arti yang pertama, yakni pengajaran dan/atau pelajaran. Bahkan, belakangan ini kata tersebut diartikan sebagai pembelajaran. (Yusuf, 2010).

Komunikasi dalam sistem instruksional kedudukannya dikembalikan pada fungsinya yang asal, yaitu sebagai alat untuk mengubah perilaku sasaran (edukatif). Proses komunikasi diciptakan secara wajar, akrab, dan terbuka dengan ditunjang oleh faktor-faktor pendukung lainnya, baik sebagai sarana maupun fasilitas lain, dengan tujuan supaya mempunyai efek perubahan perilaku pada pihak sasaran. Perubahan yang diharapkan ini bertumpu pada tiga domain, yaitu pengetahuan, sikap, dan keterampilan (kognitif, efektif, dan psikomotor atau konatif), sesuai taksonomi dari Bloom (Yusup, 2010).

Komunikasi verbal ialah suatu bentuk kegiatan percakapan atau penyampaian pesan maupun informasi 
yang disampaikan oleh seseorang kepada orang lain, baik itu dilakukan secara lisan maupun dengan cara tertulis. Jenis komunikasi verbal diantaranya ; berbicara dan menulis, serta mendengarkan dan membaca. sesuatu yang ditulis.

Komunikasi non verbal ialah merupakan kebalikan dari komunikasi verbal yakni suatu proses komunikasi atau penyampaian pesan maupun informasi yang disampaikan oleh seseorang kepada orang lain tanpa adanya suatu ucapan atau kata-kata, akan tetapi caranya menggunakan gerakan atau isyarat.

Lima fungsi pesan nonverbal yang dihubungkan dengan pesan verbal, yaitu:

1. Fungsi Repitisi

Repitisi adalah fungsi pengulangan gagasan yang sudah disajikan secara verbal. Misalnya setelah mengatakan penolakan, menggelengkan kepala. Jadi fungsi repitisi di sini adalah menguatkan pengungkapan dengan menggunakan gelengan kepala yang memiliki makna "tidak atau bukan".

2. Fungsi Substitusi

Substitusi adalah fungsi menggantikan lambang-lambang verbal. Artinya di dalam komunikasi nonverbal memang tidak ada kata-kata yang digunakan, semuanya hanya dengan menggunakan bahasa tubuh. Misalnya tanpa sepatah katapun, seseorang menunjukkan persetujuan dengan menganggukanggukan kepala.

3. Fungsi Kontradiksi

Kontradiksi adalah fungsi menolak pesan verbal atau memberi makna yang lain terhadap pesan verbal.

4. Fungsi Komplemen

Komplemen fungsi melengkapi dan memperkaya makna pesan nonverbal. Misalnya air muka anda menunjukkan tingkat penderitaaan yang tidak terungkap dengan katakata.

5. Fungsi Aksentuasi

Aksentuasi adalah fungsi menegaskan pesan verbal atau menggarisbawahi. Aksentuasi merupakan tindakan yang ditunjukkan oleh seseorang dengan menggunakan bagian dari anggota tubuhnya disamping menggunakan kata-kata. (Mark dalam Rakhmat, 2009).

\section{Proses Instruksional}


Dalam proses instruksional ada dua penetapan strategi instruksional dan metode belajar yang dilakukan guru kepada siswa. Secara umum strategi mempunyai pengertian suatu garis-garis besar haluan untuk bertindak dalam usaha mencapai sasaran yang telah ditentukan. Jika dihubungkan dengan pembelajaran, strategi dapat diartikan sebagai pola-pola umum kegiatan guru dan peserta didik dalam perwujudan pembelajaran untuk mencapai tujuan yang telah digariskan (Trianto, 2007).

Dalam penetapan strategi instruksional variabel komunikasinya ialah penggunaan saluran. Strategi apa yang akan digunakan oleh komunikator dalam suatu kegiatan instruksional banyak ditentukan oleh situasi dan kondisi medan. Namun, penetapannya bisa dipilih dengan cara bertanya kepada diri sendiri sebagai seseorang yang akan bertugas. Contohnya bagaimanakah seharusnya saya berkomunikasi dengan mereka? Apakah akan menggunakan strategi ekspositori atau strategi inkuiri.

\section{Strategi ekspositori berkenaan} dengan pemaparan, penjelasan, atau penguraian dengan didukung oleh bermacam sumber informasi pendukung seperti buku, majalah, film, dan sumber- sumber informasi lainnya. Dengan pemaparan yang sistematis, efek komunikasi dengan menggunakan strategi ini bisa lebih meresap diterima sasaran. Sedangkan yang kedua adalah strategi inkuiri (inquiry) atau startegi penemuan (discovery). Hal ini bisa dilakukan dengan bantuan alat-alat dan sarana tertentu sebagai percobaan dengan tujuan untuk menemukan suatu kesimpulan berdasarkan hasil percobaan atau penelitian tadi. Untuk pelaksanaannya perlu disesuaikan dengan isi dan tujuan instruksional yang telah ditetapkan supaya segala kegiatannya bisa terarah dan terkendali

\section{Motivasi}

Motivasi adalah suatu dorongan kehendak yang menyebabkan seseorang melakukan suatu perbuatan untuk mencapai tujuan tertentu. Motivasi berasal dari kata motif yang berarti "dorongan" atau rangsangan atau "daya penggerak" yang ada dalam diri seseorang. Namun, secara umum ada dua jenis motivasi, yaitu motivasi intrinsik dan motivasi ekstrinsik.

Motivasi intrinsik adalah keinginan seseorang untuk melakukan sesuatu, yang disebabkan oleh faktor dorongan yang berasal dari dalam diri 
sendiri tanpa dipengaruhi oleh orang lain karena adanya hasrat untuk mencapai tujuan tertentu.

Motivasi ekstrinsik adalah keinginan seseorang untuk melakukan sesuatu yang disebabkan oleh faktor dorongan dari luar diri sendiri untuk mencapai suatu tujuan yang menguntungkan dirinya.

\section{Anak Tunagrahita}

Tunagrahita yaitu keterbelakangan mental, keadaan ini dikenal juga retardasi mental (mental retardation). Anak tunagrahita mempunyai IQ di bawah rata-rata anak normal pada umumnya. Sehingga menyebabkan fungsi kecerdasan dan intelektual mereka terganggu. Adapun karakteristik anak tunagrahita dapat dirici sebagai berikut.

Pertama, tingkat ringan. Memiliki kemampuan paling tinggi setaraf dengan anak kelas 5 SD, manpu diajar membaca, menulis, dan berhitung sederhana. Dalam sosialisasi masih mampu menyesuaikan diri dengan lingkungan sosial secara terbatas.

Kedua, tingkat sedang. Mempunyai kemampuan akademik maksimal setaraf dengan anak kelas 2 SD, biasanya sering disertai dengan gangguan motorik dan komunikasi sehingga sangat sulit untuk menyesuaikan diri dengan lingkungan, aktifitas sosialnya hanya sebatas untuk memelihara diri sendiri.

Ketiga, tingkat berat. Anak ini tidak mampu dididik maupun dilatih, kemampuannya paling tinggi setaraf anak pra-sekolah, sepanjang hidupnya anak ini bergantung pada orang lain. mampu menyesuaikan diri dengan lingkungan sosial secara terbatas.

\section{METODE PENELITIAN}

Penelitian ini menggunakan metode penelitian kualitatif yaitu merupakan penelitian yang digunakan untuk menjelaskan fenomena dengan sedalam-dalamnya melalui pengumpulan data sedalam-dalamnya (Kriyantono, 2006).

Penelitian kualitatif dipilih oleh peneliti karena ingin mengetahui dan memahami secara mendalam mengenai fenomena siswa tunagrahita berprestasi. Peneliti juga ingin menggali pengalaman subjek yaitu guru dalam menerapkan komunikasi instruksional kepada siswa tunagrahita.

Adapun wawancara yang dilakukan oleh peneliti dalam mengambil data penelitian yaitu 
dilakukan kepada guru kelas yang yang mengajar siswa tunagrahita berprestasi dan beberapa siswa tunagrahita yang berprestasi, wawancara dilakukan secara langsung dan mendalam.

Sementara untuk pendekatanya mengunakan studi kasus karena peneliti ingin mengungkap keunikan dari sebuah fenomena. Maksud unik disini, fenomena yang terjadi pada individu. Individu tersebut yaitu siswa tunagrahita. Siswa tunagrahita memiliki IQ dibawah rata-rata dan memiliki minat belajar yang rendah namun mampu mencetak prestasi bahkan lebih dari anak-anak normal lainnya. Prestasi yang didapat tidak datang begitu saja, gurulah yang berperan dalam membantu siswa tunagrahita dalam membangun prestasi tersebut.

\section{PEMBAHASAN}

Komunikasi Verbal dan Nonverbal Guru Kepada Siswa Tunagrahita Berprestasi

Dalam penelitian ini, guru bertindak sebagai pelaksana komunikasi instruksional (komunikator) dan siswa tunagrahita sebagai penerimanya (komunikan). Sebelum membantu siswa tunagrahita membangun prestasi, guru terlebih dulu mengubah cara berpikir dan perilaku siswa tunagrahita seperti apa yang diinginkan para guru dengan bantuan komunikasi verbal dan nonverbal.

Melakukan komunikasi dengan anak tunagrahita tidak sama seperti anak normal pada umumnya. Anak tunagrahita memiliki kesulitan dalam berkomunikasi. Jadi ketika berkomunikasi, harus dengan kalimat yang sederhana dan tidak berbelit-belit. Siswa tunagrahita membutuhkan waktu lebih lama untuk merespon dan memahami pesan. Maka saat guru berbicara harus dengan perlahan singkat jelas kemudian satu per satu supaya siswa tunagrahita lebih mudah untuk memahami apa yang dimaksudkan oleh guru jika tidak seperti itu mereka akan gagal mentransfer makna komunikasi dengan baik.

Di SLB C Sukapura guru menggunakan komunikasi verbal dengan jenis verbal vokal yaitu membaca dan mendengarkan dan komunikasi nonverbal berupa bahasa tubuh. Mendengar dan mendengarkan berbeda, mendengar berarti semata-mata memungut getaran bunyi sedangkan mendengarkan ialah mengambil makna dari apa yang didengar. Mendengarkan melibatkan empat unsur yakni 
mendengar, memperhatikan, memahami, dan mengingat. Membaca ialah suatu cara untuk mendapatkan informasi dari sesuatu yang ditulis. Siswa tunagrahita juga dibiasakan untuk mendengarkan guru saat bercerita. Mereka harus memperhatikan, memahami dan mengingat karena setelah itu ada proses tanya jawab dari apa yang mereka dengarkan dan dari apa yang mereka baca.

Kegiatan GLS (Gerakan Literasi Sekolah) rutin diadakan pihak sekolah untuk bisa berkomunikasi dengan siswa tunagrahita. Kegiata GLS merupakan pembiasan yang dilakukan pihak sekolah untuk melatih siswa tunagrahita membaca. Kurang lebih lima belas menit mereka harus membaca. Membaca dipercaya dapat membantu siswa tunagrahita untuk melatih bicara mereka karena mereka adalah anak-anak yang mempunyai keterbatasan dalam berbicara.

Komunikasi nonverbal yang digunakan guru berupa bahasa tubuh seperti mengangguk-anggukan kepala dan lain sebagianya. Berbeda dengan anak autis, anak tunagrahita justru senang jika ada sentuhan-sentuhan dari orang lain. Jika berkomunikasi dengan siswa tunagrahita komunikasi nonverbal mempunyai fungsi aksentuasi.

Aksentuasi adalah fungsi menegaskan pesan verbal atau menggarisbawahi. Aksentuasi merupakan tindakan yang ditunjukkan oleh seseorang dengan meggunakan bagian dari anggota tubuhnya menggunakan kata-kata. Contoh lain, ketika guru menegur dengan kata tidak harus sambil mengangkat telunjuk. Agar siswa tunagrahita paham bahwa sesuatu itu tidak boleh dilakukan

Dengan cara komunikasi yang dilakukan guru di SLB C Sukapura dikatakan berhasil ketika siswa tunagrahita mampu memahami pesan dan merespon proses komunikasi itu sendiri.

\section{Proses Instruksional Dalam Membangun Prestasi Siswa Tunagrahita}

Komunikasi verbal dan nonverbal juga dilakukan ketika memberikan instruksi kepada siswa tunagrahita. Proses instruksional terdapat strategi instruksional dan metode pembelajaran yang digunakan guru dalam memberikan instruksi kepada siswa. Strategi instruksional yang digunakan pada kegiatan komunikasi instruksional guru kepada siswa tunagrahita berprestasi 
yaitu strategi ekspositori. Strategi ini meggunakan banyak media sebagai alat pendukung dalam menjelaskan apa yang guru maksud. untuk meringankan masyarakat.

Guru menggunakan banyak media yang digunakan saat pembelajaran akan membuat siswa tunagrahita merasa senang. Contohnya mainan, gambargambar yang sudah dibuat, youtube dan lain sebagainya. Mereka tidak bisa berfikir abstrak jadi jika ada contoh kongkritnya mereka akan lebih mudah memahami apa yang dimaksud komunikator. Saat guru memberikan instruksi kepada siswa harus menggambar kucing maka guru harus membawa contoh kongkrit dari gambar tersebut. Cara tersebut termasuk ke dalam metode pembelajaran pengantaran (mediation). Karena media menjadi alat bantu dalam merangsang stimulus dan respon siswa tunagrahita. Metode ini merupakan sesuatu untuk mengantarai atau menghubungkan. Dalam pembelajaran verbal, mediator menunjuk pada proses individu menghubungkan stimulus untuk direspon.

Selain penetapan strategi instruksional dalam proses instruksional juga guru harus menetapkan metode pembelajaran. Metode pembelaran seperti apakah yang digunakan guru dalam membantu siswa tunagrahita untuk memahami dan mencapai tujuan pembelajaran.

Dalam komunikasi instruksional guru memakai cara metode belajar yang terstuktur. Mulai guru mencontohkan, siswa menyimak, lalu mereka mencobanya sendiri. Mencontohkannya pun per bagian jika satu bagian selesai lanjut ke bagian selanjutnya, siswa tunagrahita tidak bisa sekaligus karena mereka harus sedikit demi sedikit. Cara ini terus diulangi sampai siswa bisa mencobanya sendiri dan memahami apa tugas mereka. Metode seperti ini membantu siswa tunagrahita lebih mudah memahami dan akan mudah menyelesaikan tugasnya. Metode ini disebut metode drill. Selain menggunakan metode drill, guru juga mengunakan metode tanya jawab. Setelah gambar selesai guru akan menanyakan kembali kepada siswa tunagrahita tentang gambar apa dan bagian-bagian dari gambar tersebut. Cara tersebut diyakini guru akan melatih daya ingat siswa tunagrahita. Metode tanya jawab adalah metode yang lebih banyak menggunakan interaksi tanya 
jawab antara guru dengan siswa dalam proses pembelajarannya.

\section{Membangun Motivasi Siswa}

Tunagrahita Dalam Berprestasi

Komunikasi verbal dan

komunikasi nonverbal juga digunakan ketika guru memberikan motivasi kepada siswa tunagrahita. Motivasi yang diberikan guru berupa pendekatan selayaknya seorang teman bukan seorang guru. Lewat pendekatan seperti ini bisa membuat siswa tunagrahita mempercayai guru sehingga mereka mau untuk berkomunikasi. Strategi instruksional dan metode pembelajaran yang diberikan bisa membuat guru mengetahui potensi yang dimiliki siswa tunagrahita.

Moving class adalah suatu kegiatan yang diadakan oleh pihak sekolah dalam melatih siswa tunagrahita untuk menggambar dan mewarnai. Bertempat di aula sekolah kegiatan yang rutin dilakukan setiap hari selasa ini, memberikan kesempatan kepada siswa tunagrahita untuk mengeluarkan potensinya. Dari hasil gambar dan mewarnai yang sudah selesai lah guru mengetahui siapa yang memiliki potensi menggambar dan mewarnai. Setelah mengetahui potensi siswa, para guru mendukung siswa tunagrahita tersebut untuk bergabung ke kegiatan ekskul menggambar dan mewarnai agar potensinya bisa lebih berkembang. Kegiatan moving class juga menjadikan siswa tunagrahita untuk belajar disiplin, kekurangan yang dialami anak tunagrahita adalah disiplin yang kurang sehingga prestasi belajar mereka rendah.

Minat belajar yang rendah termasuk dari faktor rendahnya prestasi belajar siswa tunagrahita. Terbukti dari penelitian siswa tunagrahita berprestasi pernah menolak untuk berlatih bahkan ketika lomba sedang berlangsung ada siswa tunagrahita yang mendadak tidak mau melanjutkan mewarnai dengan alasan lelah.

Namun sebagai guru tidak dapat memaksa siswa tunagrahita, justru memberikan waktu kepada mereka sampai mereka mau kembali berlatih. Tentunya para guru selain harus sabar mereka juga mempunyai cara tersendiri untuk memotivasi siswanya dalam berprestasi. Rendahnya intelektual dan keterbelakangan mental yang dimiliki anak tunagrahita sehingga mereka memerlukan adanya motivasi dari seorang guru. Motivasi memiliki potensi penentu bagi kegiatan hidup manusia 
dalam usaha mencapai cita-cita. Motivasi ekstrinsik adalah keinginan seseorang untuk melakukan sesuatu yang disebabkan oleh faktor dorongan dari luar sendiri untuk mencapai suatu tujuan yang menguntungkan dirinya. Sedangakan motivasi instrinsik keinginan seseorang untuk melakukan sesuatu, yang disebabkan oleh faktor dorongan yang berasal dari dalam diri sendiri tanpa dipengaruhi oleh orang lain karena adanya hasrat untuk mencapai tujuan tertentu.

Motivasi yang terjadi pada siswa tunagrahita berprestasi dimulai dengan motivasi ekstrinsik, mereka harus mendapat dukungan dari luar dirinya dulu. Dorongan motivasi dari para guru misalnya. Dalam komunikasi instruksional guru melakukan pendekatan layaknya seorang teman kepada siswa tunagrahita. Meyakinkan mereka bahwa mereka memiliki potensi dengan menggunakan kata-kata sederhana dan sentuhan-sentuhan yang membuat mereka merasa bukan hanya didukung tapi juga disayangi. Cara lain dalam membangun motivasi siswa tunagrahita dengan menyebutkan namanama siswa tunagrahita yang berprestasi ketika upacara berlangsung. Cara ini diyakini guru dapat menumbuhkan semangat belajar dan berlatih bagi siswa tunagrahita yang belum berprestasi.

Setelah mereka merasakan adanya dorongan motivasi yang diberikan dari lingkungan maka dengan sendirinya motivasi dari dalam diri akan muncul misalnya siswa tunagrahita yang setiap hari berlatih menggdambar sendiri selepas sekolah tanpa suruhan dari siapapun.

Penelitian ini menggunakan teori manajemen koordinasi makna. Teori ini mengatakan setiap individu juga terdiri dari sebuah sistem interpersonal yang membantu menjelaskan aksi dan reaksi. Guru dan siswa tunagrahita melakukan komunikasi yang menciptakan aksi dan reaksi. Cara guru dalam memberikan pesan lewat komunikasi, instruksi dan motivasi membuat siswa tunagrahita memberikan reaksi. Cara guru tersebut dinyatakan berhasil ketika siswa tunagrahita dapat bereaksi dan merespon pesan yang disampaikan guru. Teori ini mempunyai tiga asumsi yang relavan dengan penelitian.

Asumsi pertama menyatakan Teori manajemen koordinasi makna menggambarkan bagaimana kita berkomunikasi dalam upaya untuk memahami dunia atau untuk 
menemukan makna. Komunikasi menciptakan dunia sosial di sekitarnya. Guru melakukan komunikasi dengan siswa tunagrahita agar memahami bagaimana dunia mereka dan potensi yang mereka miliki. Komunikasi bisa menciptakan kedekatan antara guru dengan siswa tunagrahita.

Asumsi kedua menyatakan bahwa situasi sosial diciptakan oleh interaksi. Guru tidak hanya berkomunikasi, apalagi dalam memberikan instruksi dan motivasi kepada siswa tunagrahita guru juga melakukan interaksi. Situasi ini dapat menciptakan kedekatan antara guru dengan siswa tunagrahita.

Asumsi ketiga teori manajemen koordinasi makna berkaitan dengan cara orang mengendalikan percakapan melalui makna pribadi dan makna interpersonal. Arti makna pribadi mengacu pada makna yang dicapai ketika seseorang berinteraksi dengan orang lain dan membawanya ke dalam interaksi pengalaman uniknya. Hal yang ingin dicapai guru dalam berkomunikasi memberikan instruksi dan motivasi selain untuk memahami dunia siswa tunagrahita juga untuk mengetahui potensi yang mereka miliki sehingga cara yang dilakukan guru dapat membangun prestasi. Guru mendapat pengalaman uniknya saat mendampingi siswa tunagrahita dalam mengikuti perlombaan.

\section{PENUTUP}

Simpulan dalam penelitian ini adalah jenis komunikasi verbal yang digunakan guru kepada siswa tunagrahita adalah membaca dan mendengar atau komunikasi verbal vokal sedangkan komunikasi nonverbal yang digunakan berupa bahasa tubuh. Komunikasi nonverbal kepada siswa tunagrahita memiliki fungsi aksentuasi karena komunikasi nonverbal mempertegas pesan verbal. Dalam proses instruksional guru menggunakan strategi ekspositori dan metode belajar pengantaran (mediation), Metode drill, dan Metode tanya jawab. Tahapan motivasi pada siswa tunagrahita dimulai dari motivasi ekstrinsik motivasi yang berasal dari luar dirinya, motivasi instrinsik akan muncul dengan sendirinya, terjadilah sebuah prestasi. Pencapaian prestasi akan menumbuhkan motivasi baru.

\section{REFERENSI}

Rakhmat, Jakakuddin. 2009. Psikologi Komunikasi. Bandung : PT remaja Rosdakara. 
Sugiyono. 2006. Metode Penelitian Kuantitatif Kualitatif Dan R\&D. Bandung: Alfabeta.

Yin, Robert K. 2012. Studi Kasus: Desain \& Metode. Jakarta : Raja Grafindo Persada.

Yusuf, Pawit M. 2010. Komunikasi Instruksional: Teori dan Praktik. Jakarta : Bumi Aksara.

\section{B. Referensi Jurnal / Skripsi}

Afifah, Nur. Tjutju Soendari. 2017. Meningkatkan Kemampuan Berbicara pada Anak Tunagrahita Sedang Melalui Media Gambar di SLB B-C YPLAB Kota Bandung. Fakultas Ilmu Pendidikan. Universitas Pendidikan Indonesia.

April, Ismaliza. 2017. Penggunaan Komunikasi Instruksional Oleh Pendidik di Taman Pendidikan Al Qur'an. Universitas Negeri Palu. Sulawesi Barat.

Bil Haiq, Aniq Hudiyah. 2016. Efikasi diria anak berkebutuhan khusus yang berprestasi di Bidang Olahraga. Fakultas Psikologi. Universitas muhammadiyah. Surakarta.

Isnaini, Rahmi. 2008. Komunikasi Instruksional Guru dan Murid Autis di Sekolah Dasar Insania Jatiasih Bekasi. Fakultas Dakwah dan Komunikasi. UIN Syarif Hidayatullah. Jakarta. 